\title{
AIRCRAFT TURBINE ENGINE LABYRINTH SEAL INTRODUCTION AND CFD CALCULATION
}

\author{
Čížek M.*
}

\begin{abstract}
The labyrinth seals are important part of aircraft turbine engine. Primary function of labyrinth seal is elimination air mass flow which is flowing between rotational and non-rotational part. Second function is control air mass in these cavities. In this paper is listen total temperature, static pressure and flow coefficient in typical labyrinth seal geometry
\end{abstract}

\section{Keywords: Labyrinth seal, CFD Calculation, Aircraft Turbine Engine, Total Temperature and Static} Pressure.

\section{Introduction}

This article describes air mass flow between the rotational labyrinth seal and stator wall. Cavities there does have important influence on the performance parameter of the engine. Before the labyrinth seal design begins it is important to define specific parameters of e.g. materials of sealing, how big cavity should be used etc.

Aircraft turbine labyrinth seal consist of two typical parts: rotating shaft where is designed labyrinth seal with cavities and radial clearance (Jerie, 1981). Radial clearance is important part. It does have a big influence on the final performance parameters. It should be two typical situations: big radial clearance and small radial clearance. When is set a big radial clearance, the air mass flow is a lot and this setting does have a negative influence on the performance parameters. Opposite situation is when the clearance is small. The air mass flow is low, and the performance parameters are better. But it is technically difficult to design an ideal machine where should be small radial clearance through the all technical live. Rotational labyrinth seal does have a negative effect with shaft vibrations. Based on the vibration the radial clearance is changing during operation and it is therefore difficult to predict real labyrinth seal mass flow.

Standard labyrinth seal is written in Fig. 1 where are shown typical labyrinth seal.

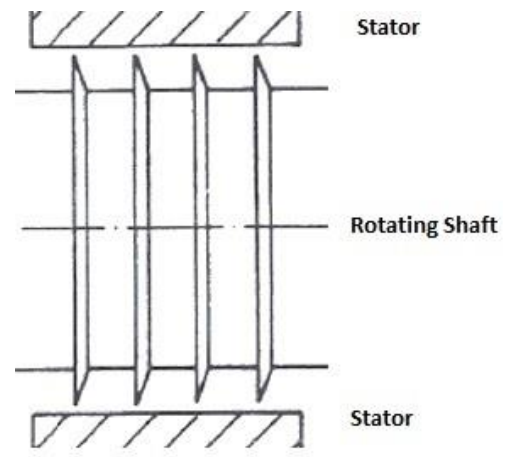

Fig. 1: Typical labyrinth seal (Jerie, 1981).

First researches were done in steam turbines (Ščeglajev, 1983) and with more advanced computational methods their quality grew (Furst, 2015, Bondarenko, 2014). But in aircraft turbine engines the circumferential speed is difficult (lower) with steam turbines comparison. Description the air flow in speed what is used in aircraft engines is the aim of this work.

\footnotetext{
* Michal Čížek.: Center of Aviation and Space Research, Faculty of Mechanical Engineering, Czech Technical University in Prague, Jugoslávských partyzánů 1580/3; 160 00, Prague 6; CZ, michal.cizek@fs.cvut.cz
} 


\section{CFD Calculation}

\subsection{Geometry}

Like typical geometry was used the rotational shaft with 6 teeth. This setting is quite usual in turbine engines, so it is shown here. It consists from 3 volumes. Inlet and outlet volumes are non-rotating and without teeth. Volumes are there only to ensure correct convergence. Last is labyrinth seal volume, which is rotating volumes and the teeth are there. All volumes are circular cuts with $5^{\circ}$ opening angle.

\subsection{Computational mesh}

The mesh was generated in ANSYS Meshing. The mesh does have $3.4 \mathrm{M}$ cells. In all walls was used the inflation for better description the air flow through the seal. For all volumes was used the "Sweep method" for better calculation in periodic sites. All cells consist from hexahedral elements - it is written in Fig. 2.

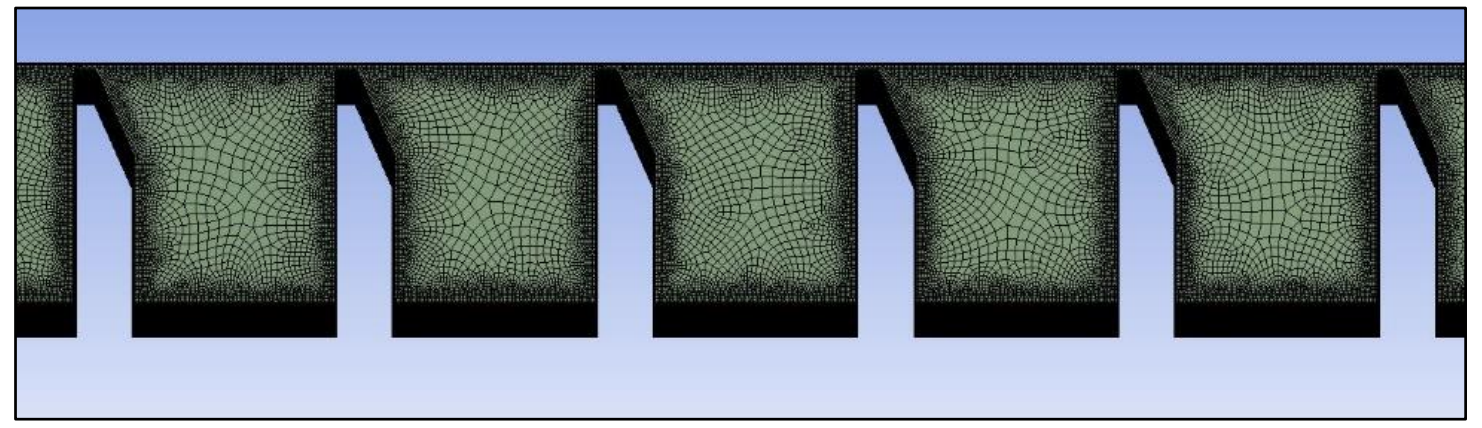

Fig. 2: Labyrinth seal volume mesh.

In critical radial clearance was generated 14 rows for better convergence and for better understanding the physics there.

\subsection{Boundary conditions and calculation preparation}

The preparation of the calculation and calculation was used in ANSYS CFX v.18 software. The inlet boundary conditions were set in Inlet volume - there are total pressure and total temperature conditions. The outlet boundary condition was set in Outlet volume - Static pressure. In labyrinth seal volume was set volume rotational speed - in opposite site (i.e. stator wall) was set the "Counter rotating wall". This conditions (i.e. constant pressure difference, inlet total temperature and speed) did not change during the calculation. It was calculated 3 variants of labyrinth seal with corrected non-dimensional radial clearance value $0.02,0.04$ and 0.06 . It is calculated based on formula:

$$
R C_{C O R R}=\frac{R C}{R C_{R E F}},
$$

where $\mathrm{RC}_{\mathrm{REF}}$ is air flow cavity without teeth. Based on (Tong, 2009 and Čížek, 2019) was used the turbulent model $\mathrm{k}-\varepsilon$. This turbulent model is better in steady state points of calculation. In walls was used scalable

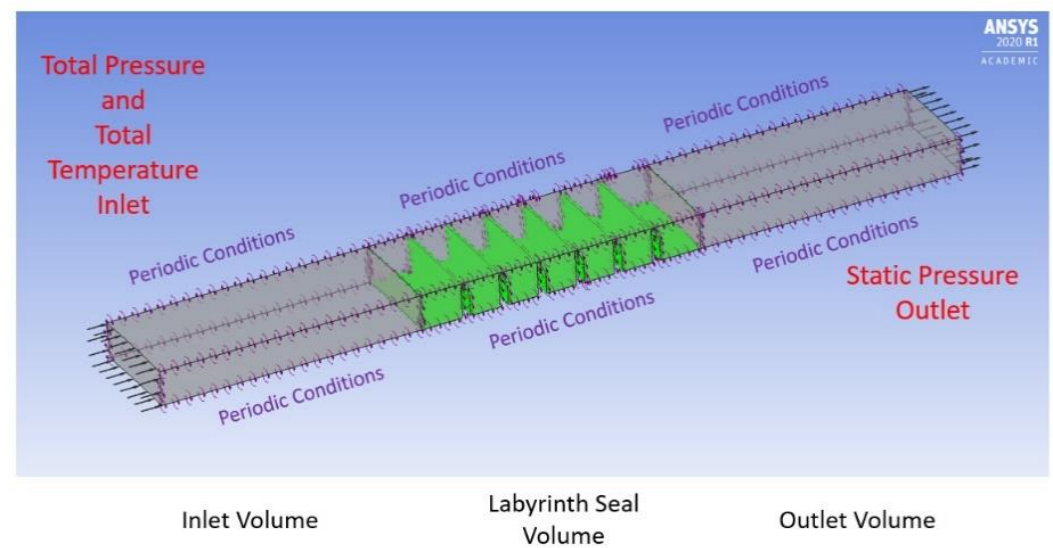

Fig. 3: Calculation Boundary Conditions. 
wall function for better creation the circumferential swirl, because the swirl has a dominant influence on the functioning of the labyrinth seal generally. All boundary conditions are written in Fig. 3.

\subsection{Calculation}

The ANSYS CFX Solver v.18 was converted in 2000 iterations in 1E-03 with physical timestep.

\subsection{Calculated data analysis}

Three variants of radial clearances were calculated. In all variants were plotted total temperature distribution, static pressure and flow coefficient through the seal with 6 teeth.

$$
\begin{gathered}
\mathrm{p}_{\text {SCORR }}=\frac{p_{S}}{p_{\text {SREF }}}, \\
T_{\text {TCORR }}=\frac{T_{T}}{T_{\text {TREF }}}, \\
\mu=\frac{Q}{Q_{C R I T}},
\end{gathered}
$$

where: $\mathrm{p}_{\mathrm{S}}$ is static pressure $[\mathrm{Pa}], \mathrm{T}_{\mathrm{T}}$ is total temperature $[\mathrm{K}], \mu$ is flow coefficient [-] and $\mathrm{Q}_{\text {CRIT }}$ is critical mass flow $[\mathrm{kg} / \mathrm{s}]$ which is calculated based on formula (5):

$$
Q_{C R I T}=\pi \cdot R C^{2} \cdot \sqrt{\frac{2 \cdot k}{k+1} \cdot r \cdot T_{0}} \cdot\left[\rho_{0} \cdot\left(\frac{2}{k+1}\right)^{\frac{1}{k-1}}\right],
$$

where $\mathrm{k}$ is Poisson constant $[-], \mathrm{r}$ is gas constant $[\mathrm{J} / \mathrm{kg} / \mathrm{K}]$ and $\rho$ is air density $\left[\mathrm{kg} / \mathrm{m}^{3}\right]$. Parameters that are indexed 0 are ambient parameters. Reference parameters (are indexed REF) are parameters from standard aircraft turbine engine operation cycle.

After calculation was analyzed the total temperature cross section of the labyrinth seal with 3 different radial clearances are written in Fig. $4: \div 6$.

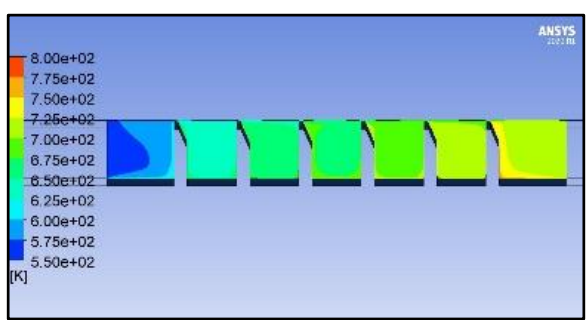

Fig. 4: Total Temperature when $R C_{C O R R}=0.02$.

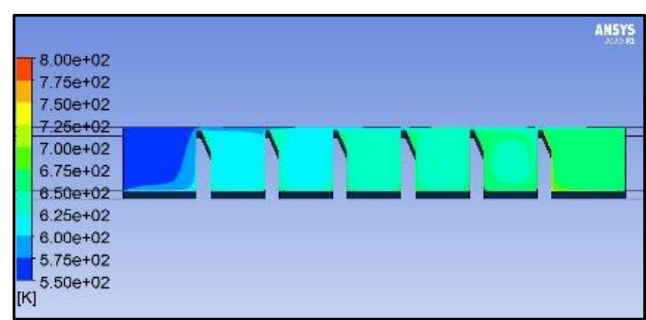

Fig. 5: Total Temperature when $R C_{C O R R}=0.04$.

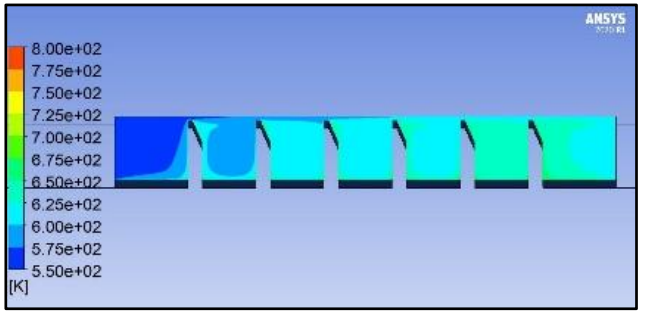

Fig. 6: Total Temperature when $R C_{C O R R}=0.06$.

Total temperature, static pressure distribution and flow coefficient are written in Fig. 7 and 8.

\section{Results}

From the previous charts shows that the static pressure degreased. It sounds logic, because it is the reason, why labyrinth seal use. Flow coefficient is little degreasing - in higher radial clearance is negligible. Interesting is total temperature increase. In the chart Fig. 7 is written that total temperature, unlike what is written in (Ščeglajev, 1983) for steam turbines, was increased about approx. 0.3. It is not so small number and should be interesting analyze this effect in the future. 


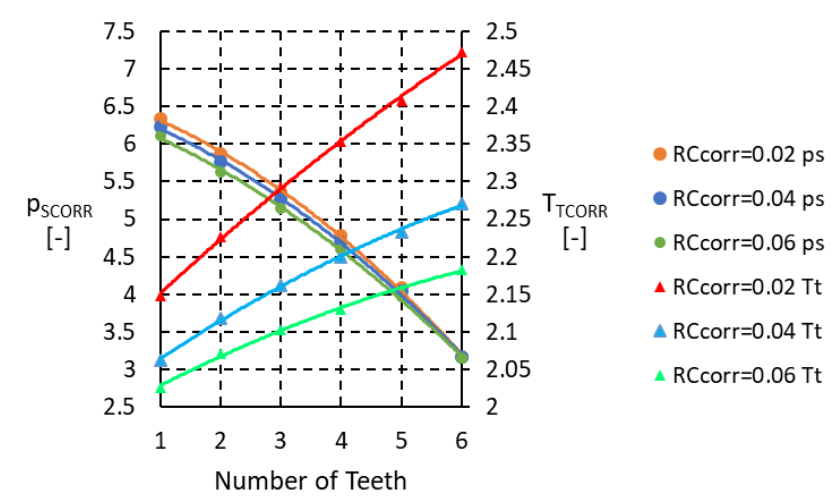

Fig. 7: Static Pressure (primary axis) and Total Temperature (secondary axis) distribution.

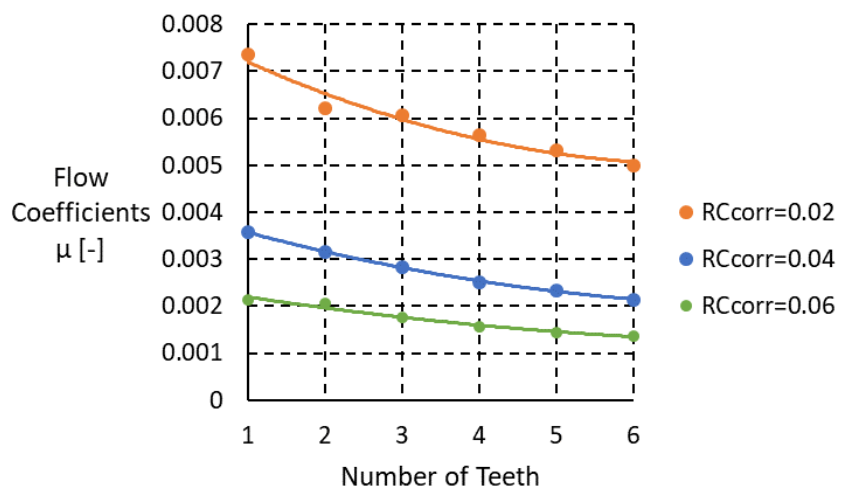

Fig. 8: Flow Coefficient distribution.

\section{Acknowledgement}

Authors acknowledge support from the ESIF, EU Operational Programme Research, Development and Education, and from the Center of Advanced Aerospace Technology (CZ.02.1.01/0.0/0.0/16_019/ 0000826), Faculty of Mechanical Engineering, Czech Technical University in Prague.

\section{References}

Bondarenko, G. A., Baga, V. N., Bashlak, I. A. (2014) Flow Simulation a Labyrinth Seal, Applied Mechanics and Materials, vol. 630, pp. 234-239.

Č́žek, M. (2019) 3D CFD Research of Labyrinth Seal Cavities of Aircraft Turbine Engine, New Trends in Aviation Development.

Furst, J. (2015) Numerical simulation of flows through Labyrinth seals, Applied Mechanics and Materials 821:16-22. Jerie, J. (1981) Engine theory, CTU in Prague, pp. 332-348, (in Czech).

Ščeglajev, A. V. (1983) Stream turbines, Státní nakladatelství technické literatury, pp. 229-242, (in Czech).

Tong, S. K., Kyu, S. Ch. (2009) Comparative analysis of the influence of labyrinth seal configuration on leakage behavior, Jornal of Mechanical Science and Technology 23: 2830-2838. 